\title{
The role of neck wrinkles for cosmetic effect during carotid artery endarterectomy
}

\section{Użyteczność zmarszczek na szyi dla efektu kosmetycznego przy operacyjnym udrożnianiu tętnicy szyjnej}

\author{
Arkadiusz Kazimierczak, Anita Rybicka, Paweł Szumiłowicz, Piotr Gutowski, Halina Kupicz, Rabih Samad, \\ Tomasz Zakrzewski, Marcin Śledź
}

Klinika Chirurgii Naczyniowej, Ogólnej i Angiologii Pomorskiego Uniwersytetu Medycznego w Szczecinie al. Powstańców Wlkp. 72, 70-111 Szczecin

Kierownik: prof. dr hab. n. med. Piotr Gutowski

\begin{abstract}
SUMMARY
Introduction: Minimally invasive procedures in carotid endarterectomy are currently preferred. Smaller skin incisions (transverse or longitudinal) and the mapping of carotid artery bifurcation with Doppler ultrasound are promoted. There is a lack of papers about cosmetic effects and patients' preferences.

The aim of this study was to qualify natural skin wrinkles as potential anatomical markers of carotid artery bifurcation and scar camouflage.

Material and methods: 50 patients underwent carotid endarterectomy in 2013-2014 in the Vascular Surgery Department of the Pomeranian Medical University in Szczecin. The positions of wrinkles were compared with the anatomical location of carotid artery bifurcation with the use of Doppler - Duplex Ultrasound. Patients' preferences and cosmetic effect were also assessed.
\end{abstract}

\section{STRESZCZENIE}

Wstęp: Metody małoinwazyjne w operacyjnym udrożnieniu tętnic szyjnych są aktualnie preferowane. Postulowane jest mniejsze cięcie zarówno podłużne, jak i poprzeczne oraz mapowanie położenia rozwidlenia tętnicy przy użyciu USG. Nie ma doniesień oceniających końcowy efekt kosmetyczny i preferencje samych pacjentów. Celem pracy była ocena przydatności naturalnych bruzd na skórze jako potencjalnych markerów anatomicznych rozwidlenia tętnicy szyjnej oraz kamuflażu blizny po operacji.

Materiał i metoda: Grupa 50 chorych leczonych operacyjnie z powodu zwężenia tętnicy szyjnej w latach 2013-2014 w Klinice Chirurgii Naczyniowej Pomorskiego Uniwersytetu Medycznego w Szczecinie. Oceniana była anatomiczna przydatność położenia zmarszczek w stosunku do rozwidlenia tętnicy szyjnej, preferencje pacjentów w stosunku do skutku kosmetycznego proponowanego dostępu operacyjnego i przydatność USG do mapowania rozwidlenia tętnicy szyjnej.
Results: $50 \%$ of patients declared the cosmetic effect important. Nevertheless, every patient preferred a transverse incision along a wrinkle line. The wound scar was invisible in $76 \%$ of cases 3-6 months after surgery. Wrinkles were close, within 1 centimeter, to carotid artery bifurcation in $80 \%$ of cases. It was mainly $4-5 \mathrm{~cm}$ from the angle of the mandible. Surgical access along wrinkles located 3, 4, 5, 6, $7 \mathrm{~cm}$ from the gonial angle was technically easy in 55\%, 77\%, 79\%, 45\%, and $21 \%$ of cases, respectively. Using ultrasound before surgery allows the planning of the optimal incision in $98 \%$ of cases.

Conclusions: Transverse incision hidden in the wrinkles of the neck gives a good cosmetic effect and allows carotid endarterectomy in every case when carotid artery bifurcation is marked prior to surgery.

Key words: carotid endarterectomy, minimally invasive surgery, USG guided mapping.

Wyniki: Tylko 50\% chorych deklaruje, że zależy im na efekcie kosmetycznym, mimo to wszyscy wybierają dostęp w linii zmarszczek. Po operacji nie było widać w ogóle blizny u 76\% chorych po cięciu w bruździe skórnej. Bruzdy skórne umiejscowione nad rozwidleniem tętnicy szyjnej w $80 \%$ znajdują się 4-5 cm od kąta żuchwy. Z cięcia w najczęstszych lokalizacjach bruzd skórnych na poziomach 3, 4, 5, 6 i $7 \mathrm{~cm}$ od kąta żuchwy można łatwo technicznie wykonać odpowiednio 55\%, 77\%, 79\%, $45 \%$ i $21 \%$ zabiegów. Użycie USG przed zabiegiem umożliwia ustalenie optymalnego dostępu w 98\% przypadków.

Wnioski: Wybór cięcia poprzecznego przebiegającego w bruzdach na szyi daje dobry efekt kosmetyczny i umożliwia wykonanie udrożnienia tętnicy szyjnej w każdym przypadku, jeśli przed zabiegiem potwierdzi się korzystne położenia jej rozwidlenia. Słowa kluczowe: zwężenie tętnic szyjnych, chirurgia naczyniowa, mapowanie położenia za pomocą USG.

\section{INTRODUCTION}

Carotid endarterectomy is the most common preventive procedure in vascular surgery. Qualification for surgery is a stenosis of the internal carotid artery over $70 \%$, or $50 \%$ if symptomatic
WSTĘP

Operacja z powodu zwężenia tętnic szyjnych jest najczęściej wykonywaną operacją prewencyjną w chirurgii naczyniowej. Do jej wykonania kwalifikuje się zwężenia tętnic szyjnych 
(cerebrovascular episodes within 6 months before surgery). There are generally 2 methods of treatment for carotid artery stenosis: endovascular carotid artery stenting (CAS) and operative carotid endarterectomy (CEA) [1]. Carotid artery stenting procedures are preferred for patients with a high risk of cardiovascular complications and specific anatomy (high level of carotid artery bifurcation), restenosis after CEA, previous surgery and radiotherapy on the neck, and patients with recurrent nerve paralysis on the opposite side. There are a few types of surgical treatment too: classical, everted, and with path plasty. But there are not any specific recommendations to use any of these. Surgeons should use a method providing the best results, meaning complication (e.g. strokes and perioperative cardiac infarctions) below 3\% [1]. Recently minimally invasive procedures are more popular due to their cosmetic effect. They are technically more complicated, and sometimes demand mapping of carotid artery bifurcation with Doppler ultrasound before operation $[2,3,4]$, especially when a small skin incision is planned $[2,3]$. It is worth doing because the results of minimally invasive procedures are comparable with classical operations $[2,3,4]$. All scars made beyond the Langer lines are more visible, and it is worth using the existing wrinkles. Patient preferences regarding cosmetic effect and postoperative comfort (pain) also seem to be important. There is a question of whether there is any sense in doing a less invasive procedure when the patient does not care about cosmetic effect.

The aim of this study was to identify patients' preferences regarding the cosmetic effect of the operation (classical incision along the sternocleidomastiodeus muscle - SCM and transverse incision along wrinkles). The wrinkles' position as a potential marker of carotid artery bifurcation before surgery was evaluated. The cosmetic effect and complication rate (summary of the number of strokes and cardiac infarctions and nerve damage) after 2-4 months and after 1 year post operation were assessed.

\section{MATERIAL AND METHODS}

50 patients were operated on due to carotid artery stenosis. Before surgery patients were informed about the technical aspects of the proposed operation according with ESVS indications and patient agreement. Every patient was asked about operation preferences (transverse incision in a wrinkle closest to the carotid artery bifurcation) or a classical incision along the SCM muscle. In all patients the position of wrinkles on the neck and the distance from the gonial angle were assessed. The carotid artery bifurcation was mapped in all patients using Doppler ultrasound and comparison between the gonial angle and skin wrinkles. The incision was made in the wrinkle that was up to $1 \mathrm{~cm}$ from the carotid artery bifurcation. This distance was opitimal and "convenient" for all the surgeons performing operations with this technique. After surgery the cosmetic effect, neurological complications, heart failure complications and nerve damage (sensory loss, voice changes) were assessed. Repeated clinical examinations were done after 2, 4 and 12 months. przekraczające 70\% lub 50\%, jeśli są to zwężenia objawowe, to jest powikłane epizodem naczyniowo-mózgowym w poprzedzających zabieg 6 miesiącach [1]. Stosowane są różne metody udrażniania tętnic szyjnych - od endowaskularnych (carotid artery stenting - CAS) po operacyjne (carotid endarterectomy CEA) [1]. Do CAS kwalifikowani są w pierwszej kolejności chorzy z wysokim ryzykiem powikłań sercowo-naczyniowych oraz ze specyficzną anatomią (wysoki podział tętnicy szyjnej, restenozą po CEA, zmianach bliznowatych na szyi po operacjach i naświetlaniu, chorzy z porażeniem przeciwwstawnego nerwu krtaniowego wstecznego). Są to tak zwane klasyczne wskazania do CAS. Operacyjne leczenie również ma wiele odmian (klasyczna, ewertowana, z wszczepieniem łaty i inne), ale nie ma określonych rekomendacji potwierdzonych wyższością którejkolwiek z metod. Chirurg powinien używać tej metody, przy której osiąga najlepsze rezultaty, przy czym osiągane wyniki leczenia są ściśle rekomendowane. Oznacza to, że zsumowany odsetek udarów i okołooperacyjnych zawałów serca nie powinien przekroczyć 3 dla ośrodka [1]. W ostatnich latach popularne stają się zabiegi mniej inwazyjne jako kosmetycznie korzystniejsze. Wiążą się one czasem z większą techniczną trudnością przeprowadzenia i wymagają często tzw. mapowania położenia rozwidlenia tętnicy szyjnej przy użyciu USG przed zabiegiem [2, 3]. Szczególnie jeśli planuje się dostęp z bardzo małego cięcia $[2,3]$. Istotne jest, aby wyniki tych modyfikowanych operacji były jednakowo dobre, jak ich bardziej inwazyjne odmiany $[2,3,4]$. Niestety, wszelkie blizny po cięciu wykonanym poza liniami Langera są mniej lub bardziej widoczne. Dlatego wydaje się, że warto wykorzystać istniejące zmarszczki i zaplanować dostęp, mapując rozwidlenie tętnic szyjnych przy dostępie małoinwazyjnym. Jednak wobec różnorodności podejścia do operacyjnego leczenia zwężenia tętnic szyjnych, oczywistym faktem wydaje się również wzięcie pod uwagę preferencji chorego co do kosmetyki proponowanego leczenia oraz komfortu po operacji (ból i samoakceptacja). Lecz czy jest sens wykonywać trudniejsze technicznie zabiegi, jeśli efekt kosmetyczny okazałby się nieistotny dla pacjenta?

Celem pracy była ocena preferencji chorych w stosunku do kosmetycznego efektu proponowanego leczenia (cięcie klasyczne wzdłuż mięśnia mostkowo-obojczykowo-sutkowego czy miniinwazyjne, tj. poprzeczne w linii zmarszczek). Zbadanie przydatności rozkładu położenia zmarszczek na szyi jako potencjalnych markerów rozwidlenia tętnicy szyjnej. Wreszcie ocena efektu kosmetycznego i powikłań (zsumowany odsetek udarów i zawałów serca oraz uszkodzeń nerwów czaszkowych) po 2-4 miesiącach i po roku obserwacji.

\section{MATERIA $~ I$ METODY}

Z powodu zwężenia tętnic szyjnych było operowanych 50 pacjentów. Przed operacją chorzy byli informowani o technicznych aspektach proponowanego leczenia zgodnie z aktualnie stosowanym formularzami świadomej zgody i zgodnie z zaleceniami ESVS [1]. Każdy chory został zapytany o preferowany sposób 
$100 \%$ of the patients agreed do be operated on with an incision along the wrinkles. No patients wanted to be operated on with an incision along the sternocleidomastoideus muscle, but only $50 \%$ of the patients declared that they care about the cosmetic effect as much as about the surgical effect of endarterectomy. Wrinkle location, the number of wrinkles, and the distance from the carotid artery bifurcation are shown in Figure 1.

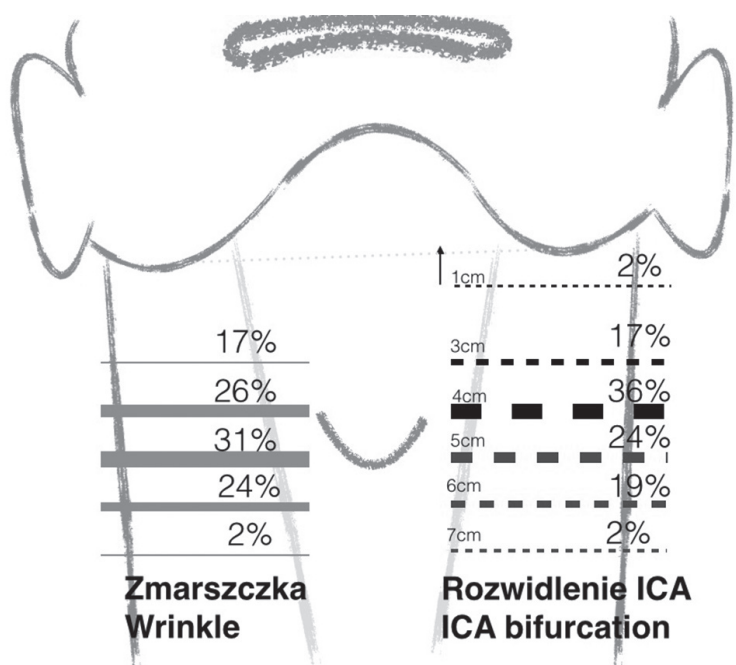

ICA - internal carotid artery / udrożnienie tętnic szyjnych

FIGURE 1. Location of wrinkles and their distance from the carotid artery bifurcation

RYCINA 1. Lokalizacja zmarszczek oraz ich odległość od rozwidlenia tętnicy szyjnej

In the group of 50 patients only one had a high level of carotid artery bifurcation making the operation technically impossible. This patient was qualified to CAS. In the rest of the cases 1 or 2 wrinkles at least $10 \mathrm{~mm}$ from the carotid artery allowed for safe and comfortable operation. Most wrinkles were located 4-5 cm from the carotid artery bifurcation (Table 1).

Strokes and acute coronary syndromes were observed in $3.1 \%$ of patients after 2 months, and in $4.7 \%$ of patients after 1 year. Two patients died between 2-12 months after operation. Nerve damage was present in $6 \%$ of patients 2 months afar surgery, and in $8.7 \%$ within 1 year. $98 \%$ of patients were satisfied with the cosmetic effect. Good cosmetic result (scar almost invisible or camouflaged in the wrinkle) was achieved in $76 \%$ of patients (Figure 2).

\section{DISCUSSION}

The first papers about the good effects of mini-invasive carotid endarterectomy were presented in 2005 [2]. There were comparisons of both methods (longitudinal and transverse incision) with comparable results regarding the number operacji (tj. z cięcia poprzecznego w bruździe/zmarszczce położonej najbliżej rozwidlenia tętnicy szyjnej lub klasycznego wzdłuż mięśnia mostkowo-obojczykowo-sutkowego). Wszystkim chorym przed zabiegiem określano liczbę i położenie zmarszczek na szyi oraz ich odległość od kąta żuchwy. U wszystkich określano przed operacją położenie rozwidlenia tętnicy szyjnej za pomocą USG. Na dostęp operacyjny wybierano tę bruzdę skórną, która była oddalona od rozwidlenia tętnicy na maksymalnie $1 \mathrm{~cm}$. Dystans ten był optymalnym i „komfortowym” dla wszystkich chirurgów wykonujących zabieg tą techniką. Wszyscy chorzy zostali pierwotnie zakwalifikowani do operacji z cięcia poprzecznego zgodnie ze swoją wolą oraz preferencjami operującego chirurga. Po zabiegu oceniano efekt kosmetyczny, wystąpienie powikłań neurologicznych i sercowo-naczyniowych oraz uszkodzenia nerwów obwodowych (zaburzenia czucia, zmiana barwy głosu itp.). Ponowną ocenę kliniczną przeprowadzono 2-krotnie, tj. po 2-4 miesiącach oraz roku od operacji.

\section{WYNIKI}

Po zapoznaniu się z informacją o proponowanym leczeniu, $100 \%$ pacjentów wyraziło chęć poddania się operacji z cięcia poprzecznego w linii zmarszczek. Mając wybór, żaden chory nie chciał się zgodzić na klasyczne, podłużne cięcie wzdłuż mięśnia mostkowo-obojczykowo-sutkowego. Aczkolwiek tylko $50 \%$ chorych deklarowała, że zależy im na efekcie kosmetycznym tak samo, jak na dobrym wyniku samego udrożnienia tętnicy szyjnej. Liczba zmarszczek branych pod uwagę jako kamuflaż dostępu chirurgicznego to 1, 2 lub 3. Chorych z taką liczbą zmarszczek było odpowiednio: 23\%, 54\% i 34\%. Zaobserwowane odległości od kąta żuchwy do rozwidlenia tętnicy szyjnej i najbliższej „komfortowej” zmarszczki zobrazowano na rycinie 1.

W grupie 50 chorych tylko w 1 przypadku stwierdzono wysokie położenie rozwidlenia tętnicy uniemożliwiające wygodny dostęp operacyjny. Chory ten został zakwalifikowany do CAS. W pozostałych przypadkach zawsze znajdowano 1 lub 2 bruzdy skórne w odległości do $10 \mathrm{~mm}$ od rozwidlenia tętnicy szyjnej umożliwiające „komfortowe” przeprowadzenie zabiegu. Najczęściej były to zmarszczki na 4. i 5 . centymetrze od rozwidlenia tętnicy szyjnej (tab. 1).

TABLE 1. Distribution of the convenient surgical access points depending on the distance between the wrinkle and the gonial angle

TABELA 1. Rozkład „wygodnych” dostępów chirurgicznych w zależności od odległości zmarszczek od kąta żuchwy

\begin{tabular}{cc}
$\begin{array}{c}\text { Distance between } \\
\text { wrinkle and gonial angle } \\
\text { Odległość zmarszczki } \\
\text { od kąta żuchwy }\end{array}$ & $\begin{array}{c}\text { Location of the carotid artery bifurcation } \\
\text { within } 10 \mathrm{~mm} \text { from the wrinkle } \\
\text { Położenie rozwidlenia tętnicy szyjnej } \\
\text { w zasięgu do 10 mm od bruzdy skórnej }\end{array}$ \\
\hline $3 \mathrm{~cm}$ & $55 \%$ \\
\hline $4 \mathrm{~cm}$ & $77 \%$ \\
\hline $5 \mathrm{~cm}$ & $79 \%$ \\
\hline $6 \mathrm{~cm}$ & $45 \%$ \\
\hline $7 \mathrm{~cm}$ & $21 \%$ \\
\hline
\end{tabular}




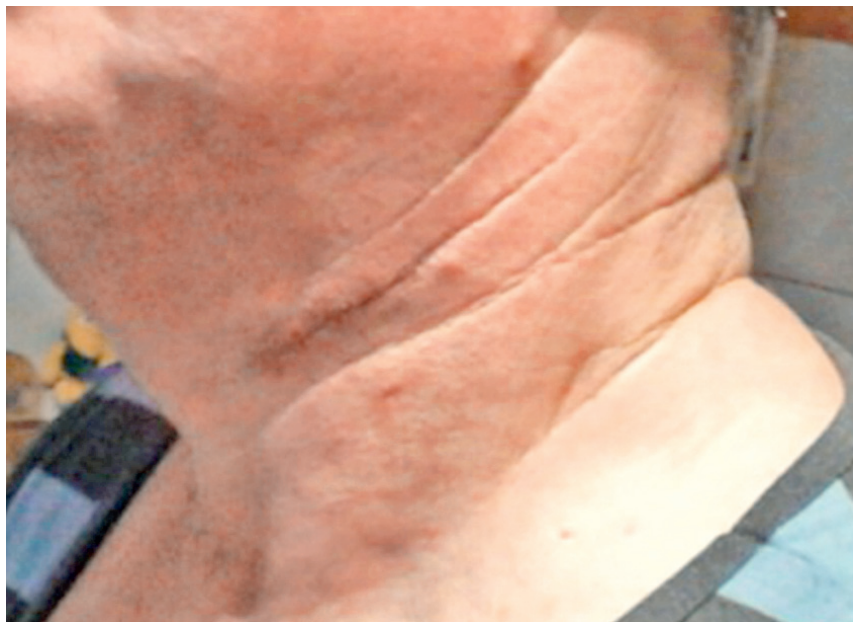

FIGURE 2. The scar camouflaged in a wrinkle line

RYCINA 2. Blizna ukryta w linii zmarszczek

of strokes and nerve injuries [3, 4]. All authors highlighted mapping carotid artery bifurcation before the operation with Doppler ultrasound $[2,3,4]$. Longitudinal incision allows easier performing of carotid artery endarterectomy, but unfortunately this is not along Langer lines, resulting in a small but visible scar $[4,5]$. Minimization of the incision along the sternocleidomastoideus muscle resulted in a bad cosmetic effect and a complicated operation $[4,6]$. In our experience transverse incision did not cause any technical problems during the operation when the distance from the incision to the bifurcation of the carotid artery was less than $1 \mathrm{~cm}$. However, longer distance allows the performing of the operation, but it is technically demanding and time consuming. The number of strokes and coronary episodes was not higher, comparing results to the "classic longitudinal incision". We did not observe a higher incidence of nerve damage. Comparable results are reported by other clinics using less invasive techniques [6]. Risk of nerve damage is not connected with surgical access, but with surgical technique on the artery. For example, in the everted method more sublingual nerve damage is observed. Nevertheless, the mini-invasive method is safe and has started to be more popular. However, nobody until now has asked the patients about their preferences of operation method. On the other hand, if patients are asked about their preferences or treatment method in carotid artery disease, half of them would like to be treated only pharmacologically [7]. The rest of them would choose carotid artery stenting or crotid endarterectomy. This is usually the group of young smokers [7]. For the patients who decide to be operated on, cosmetic effect seems to be important either way (half of patients). However, all patients would choose the mini-invasive incision due to better cosmetic effect if similar operation results are expected $[3,4]$. Wrinkles on the neck might be the universal marker to do the incision in the proper place. Usually, an incision in the wrinkle located 4-5 $\mathrm{cm}$ from the gonial angle allows the performing of "convenient for the surgeons" $80 \%$ of operation. However, there are a small number of cases with less visible wrinkles or with
Zsumowany odsetek zawałów i udarów mózgu do 2 miesięcy po operacji wyniósł 3,1, a w ciągu roku obserwacji osiągnął 4,7. Pomiędzy 2. a 12. miesiącem obserwacji zmarło 2 chorych. Uszkodzenia nerwów czaszkowych obserwowano u 6\% do 2 miesięcy po zabiegu i u 8,7\% do roku. Zadowolonych z efektu kosmetycznego było $98 \%$ chorych. Za dobry efekt uznawano bliznę, której nie było widać w ogóle lub trudno było ją prześledzić wzdłuż bruzdy skórnej (ryc. 2). Taką sytuację zastano u $76 \%$ pacjentów.

\section{DYSKUSJA}

W 2005 r. pojawiły się doniesienia o korzyściach z wykonywania operacji z małego cięcia [2]. Porównywano różne metody małych cięć (podłużne i poprzeczne), wykazując jednakowe wynik w kwestii ryzyka udarów i uszkodzeń nerwów obwodowych [3, 4]. Wszyscy autorzy podkreślali konieczność mapowania położenia rozwidlenia tętnicy szyjnej przed operacją przy użyciu USG [2, 3, 4]. Podkreślano, że cięcie podłużne ułatwia operację, ale niestety przebiega w sprzeczności do linii Langera i pozostawia małą, ale widoczną bliznę [4, 5]. Minimalizowanie długości cięcia, ale wykonywanie go nadal wzdłuż mięśnia mostkowo-obojczykowo-sutkowego wcale nie poprawia efektu kosmetycznego, utrudniając istotnie sam zabieg [4, 6]. W ośrodku autorów publikacji, stosując cięcie poprzeczne w zmarszczce, nie napotkano dotąd istotnej technicznej przeszkody w wykonaniu zabiegu, jeśli odległość cięcie-rozwidlenie tętnicy szyjnej nie przekraczała $1 \mathrm{~cm}$. Większe odległości nie uniemożliwiałyby co prawda operacji, ale znacznie by ją przedłużały ze względu na trudniejszy dostęp operacyjny. Zaobserwowany w badaniach własnych zsumowany odsetek udarów i zawałów serca nie przekraczał akceptowalnych granic $[3,4]$. Nie obserwowano też zwiększonego odsetka późnych uszkodzeń nerwów obwodowych. Potwierdza to obserwacje z ośrodków stosujących małoinwazyjne dostępy w chirurgii tętnic szyjnych [6]. Ryzyko uszkodzenia nerwów czaszkowych nie wiąże się bowiem z dostępem do operacji, ale raczej ze sposobem przeprowadzenia zabiegu na samej tętnicy. Jedna z metaanaliz dowodzi w tym wypadku, że w ewertowanej metodzie operacji częściej dochodzi do uszkodzeń nerwu podjęzykowego [6]. Choć podejście małoinwazyjne jest bezpieczne i obecnie modne, to jednak nikt nie ocenił preferencji samych chorych co do wyboru dostępu operacyjnego. Tym bardziej, że jeśli zapytać pacjentów o to, jak wolą być leczeni, połowa opowie się tylko za leczeniem farmakologicznym [7]. Reszta wybierze operacje lub stentowanie i będą to głównie względnie młodzi palacze [7]. Dla części chorych, którzy zdecydują się jednak na leczenie operacyjne, efekt kosmetyczny będzie miał istotne znaczenie. Pomimo że jest to tylko połowa chorych z obserwacji własnej, to jednak wszyscy chcą być operowani z cięcia korzystniejszego kosmetycznie, zakładając oczywiście, że wyniki operacji będą podobne [3, 4]. Układ zmarszek na szyi pozwala wygodnie dostać się do tętnicy, ale nie da się określić uniwersalnego wzorca opartego wyłącznie na położeniu bruzdy skórnej. Co prawda z cięcia w bruździe skórnej 
a large distance from the carotid artery bifurcation, especially in obese patients. In these cases the long distance of the incision from the carotid artery bifurcation can make the operation difficult. Doppler ultrasound allows the choice of the wrinkle to make the right incision, and should be used routinely $[2,3,4]$. Usually, patients have at least 2 wrinkles on the neck, so 1 of them, in a more convenient location, can be used (Figure 1). Only $20 \%$ of patients had one wrinkle on the neck. However, we did not notice any case in which wrinkle location would disable making an incision at the convenient surgical access.

\section{CONCLUSIONS}

A transverse incision camouflaged in the wrinkles of the neck gives a good cosmetic effect and allows carotid endarterectomy in every case when carotid artery bifurcation is marked prior to surgery. można wykonać każdą operację udrożnienia tętnicy szyjnej, ale wybierając zmarszczkę oddaloną od kąta żuchwy na 4-5 cm uda się komfortowo wykonać ponad 80\% zabiegów. Pozostaje jednak niewielki odsetek chorych, u których zmarszczki są mało widoczne lub oddalone znacznie od rozwidlenia tętnic, lub też samo rozwidlenie ma anatomiczne odmienne położenie. Ma to szczególne znaczenie u otyłych chorych. W takich przypadkach znaczna odległość cięcia od tętnicy może utrudnić i przedłużyć operację. Dlatego określenie położenia rozwidlenia tętnicy za pomocą USG przed operacją umożliwia wybór odpowiedniej zmarszki ze 100\% pewnością powodzenia i powinno być rutynowo stosowane [2, 3, 4]. Na szczęście ponad połowa chorych ma co najmniej 2 bruzdy skórne, co ułatwia dokonanie wyboru wygodniejszego cięcia (ryc. 1). Tylko 20\% chorych ma 1 bruzdę, ale nie zaobserwowano na razie żadnego przypadku, w którym umiejscowienie zmarszczki uniemożliwiłoby wykonanie zabiegu z cięcia w niej kamuflowanego.

\section{WNIOSKI}

Wybór cięcia poprzecznego przebiegającego w bruzdach na szyi daje dobry efekt kosmetyczny i umożliwia wykonanie udrożnienia tętnicy szyjnej w każdym przypadku, jeśli przed zabiegiem potwierdzi się korzystne położenia jej rozwidlenia.

\section{REFERENCES / PIŚMIENNICTWO}

1. Liapis C.D., Bell P.R.F., Mikhailidis D., Sivenius J., Nicolaides A., Fernandes J. et al: ESVS Guidelines. Invasive treatment for carotid stenosis: indications, techniques. Eur J Vasc Endovasc Surg. 2009, 37, 1-19.

2. Ascher E., Hingorani A., Marks N., Schutzer R.W., Mutyala M., Nahata S. et al.: Mini skin incision for carotid endarterectomy (CEA): a new and safe alternative to the standard approach. J Vasc Surg. 2005, 42 (6), 1089-1093.

3. De Troia A., Mosso F., Biasi L., Corona P., Tecchio T., Azzarone M. et al.: Carotid endarterectomy with mini-invasive access in locoregional anaesthesia. Acta Biomed. 2008, 79, 123-127.

4. Marcucci G., Antonelli R., Gabrielli R., Accrocca F., Giordano A.G., Siani A.: Short longitudinal versus transverse skin incision for carotid endarterec- tomy: impact on cranial and cervical nerve injuries and esthetic outcome. J Cardiovasc Surg (Torino). 2011, 52 (2), 145-152.

5. Langer K.: On the anatomy and physiology of the skin. Br J Plast Surg. 1978, 31 (1), 3-8.

6. Bartolucci R., D’Andrea V., Leo E., De Antoni E.: Cranial and neck nerve injuries following carotid endarterectomy intervention. Review of the literature. Chir Ital. 2001, 53 (1), 73-80.

7. Jayasooriya G.S., Shalhoub J., Thapar A., Davies A.H.: Patient preference survey in the management of asymptomatic carotid stenosis. J Vasc Surg. 2011, 53 (6), 1466-1472. 